\title{
ResearchArticle
}

\section{Effectiveness of botanicals and chemicals against Bihar hairy caterpillar (Spilarctia obliqua) in cowpea}

Ved Prakash and Arun Kumar Singh

\section{SUMMARY}

The Bihar hairy caterpillar is an important pest of cowpea in central part of Uttar Pradesh. Its infestation caused high plant mortality which resulted in reduction in yield. Botanicals and chemicals components were fast and highly effectiveness against Spilarctia oblique viz., endosulfan (foliar spray), carbofuran + bavistin (seed treatment), botanical and organic Panchgavaya (foliar spray), ipomea leaf (foliar spray), ipomea leaf + cow urine fermented (foliar spray), callotropis leaf (foliar spray), callotropis leaf + cow urine fermented (foliar spray), were evaluated during Kharif 2016 and 2017 at the University farm. All the insecticidal treatments were significantly superior to untreated check. Amongst these, maximum and minimum insect mortality was observed in endosulfan (70.83\%) and ipomea leaf+cow urine $(31.13 \%)$ treated plots, respectively.

Key Words : Spilarctia oblique, Botanicals, Organic, Chemicals

How to cite this article : Prakash, Ved and Singh, Arun Kumar (2019). Effectiveness of botanicals and chemicals against Bihar hairy caterpillar (Spilarctia obliqua) in cowpea . Internat. J. Plant Sci., 14 (2): 66-68, DOI: 10.15740/HAS/IJPS/14.2/66-68, Copyright@ 2019: Hind Agri-Horticultural Society.

Article chronicle : Received : 11.02.2019; Revised : 04.06.2019; Accepted : 14.06.2019

\author{
$\longrightarrow$ MEMBERS OF THE RESEARCH FORUM \\ Author to be contacted : \\ Arun Kumar Singh, Department of Entomology, Narendra Deva \\ University of Agriculture and Technology, Narendra Nagar (Kumarganj) \\ Aayodhya (U.P.) India \\ Email : arunent88@gmail.com
}

Address of the Co-authors:

Ved Prakash, Department of Entomology, Institute of Agricultural

Sciences, Bundelkhand University, Jhansi (U.P.) India 